\title{
INVESTIGATION OF CONSUMER ATTITUDES FROM THE PERSPECTIVE OF CONSUMER BASED BRAND EQUITY ON TRACKSUIT BRANDS
}

\author{
Yavuz Yıldız, Alper Kinden \\ Celal Bayar University, Manisa, Turkey
}

\begin{abstract}
Background. Brand equity has a positive impact on consumers' selection of products and services, their perception, purchasing intentions, their willingness to pay more for brands. Brand equity is designed to reflect the real value from the perspective of consumer that a brand name holds for the products and services. Measuring brand equity is important because brands are believed to be strong influencers of business outcomes, such as sales and market share. The aim of this study was to describe the brand equity of tracksuits and investigate the purchasing behaviours of the tracksuit consumers.

Methods. The research sample consisted of 250 athletes who were selected via random sampling method. "Consumer-Based Brand Equity Scale", developed by Vazquez, del Rio, and Iglesias (2002), was implemented in order to measure consumer-based brand equity with regard to tracksuit brands.

Results. Results of the study showed that the consumer based brand equity did not differ by gender, age, tracksuit usage purpose, tracksuit buying timing. However, it was found that the consumer based brand equity was significantly different in the number of tracksuits owned and the amount of payment.

Conclusion. High brand equity brings the willingness to pay more for that brand. Consequently, it can be suggested that high level of consumer based brand equity enhances the amount of purchases and willingness to pay more. Although there are many studies on the brand equity in sports, such as shoes and teams, we have found no research on tracksuits. This research focuses on tracksuits' brand equity. The results of this research contribute to sports marketing literature.
\end{abstract}

Keywords: sport, sports marketing, brand equity, tracksuit.

\section{INTRODUCTION}

$\mathrm{D}$ ifferences among products have diminished significantly and almost become nonexistent due to the repercussions of fierce competitive environment. Thus, brands and branding studies have come to the fore since product-related features have lost their significance in marketing practices. In the same vein, brand management has been in the limelight as a result of endeavours to enhance efficiency and profitability (Aktuğlu, 2008).

Brands are appreciable assets which contribute to the reputation of products and enterprises while ensuring customer satisfaction, competitive advantage and willingness to pay more if managed effectively. According to Tek and Özgül (2005), brands bring concrete benefits to enterprises such as legal protection, differentiation from rivals and publicity of products. Moreover, brands allow products to take on identity, increase competitive power and prevent price competition. Farquhar (1989) defines products as concrete assets with functional benefits such as toothpaste, insurance policy or a car. Brand is a name, symbol, design or sign increasing the value of a product beyond its functional benefits. From this perspective, a brand has added value for its enterprise, for the 
customers in commercial terms. Therefore, brands are potent assets which require vigilant handling and management (Kotler, Wong, Saunders, \& Armstrong, 2005). Successful brands provide a very strong link between the rational and emotional needs of consumers and what they offer as brand values (de Chernatony \& Riley, 1998). Successful brands offer ease of operation through brand and line extension. Consumers transfer their positive image and experience of a specific brand to other products of the same brand through brand and line extension (Ambler \& Styles, 1996).

Brand equity is one of the most popular topics in marketing. Creating strong brand equity has been mandatory for many enterprises as it brings about many marketing superiorities and reinforces competitive power. Brand equity entails the value that emerges when a product bearing a brand name is compared with an equivalent product without a brand name (Aaker, 1991). Brand equity can be evaluated in two ways as financial-based and consumer-based. Brand equity can be taken as attitudes, awareness, image and knowledge from the perspective of consumers or as price, market share, revenue and cash flow from the financial window (Ailawadi, Lehmann \& Neslin, 1991). Brand equity indicates what a brand signifies for a company. Consumer-based brand value depends on brand owners (or potential owners) in different ways because different owners may attain more or less of the potential value of the brand depending on their varying capabilities to strengthen brand equity. The market value of a brand is the sale or replacement value of a brand and is under the strong influence of consumer-based brand equity. Besides, consumer-based brand equity plays more of a positive role in brand acceptance (Raggio $\&$ Leone, 2007). Even though dimensions of brand equity are handled in different ways, other dimensions such as brand awareness, associations, perceived quality, brand loyalty, reputation and brand power are also taken into heed. Brand equity is the culmination of the interplay between these dimensions, hence proves to be valid both for the company and the customers. Moreover, equity created for customers has a direct contribution to the company (Yoo, Donthu, \& Lee, 2000).

According to Keller (1993), who conceptualizes consumer-based brand equity as brand knowledge, brand knowledge has two components which are brand awareness and brand image. Brand awareness pertains to recognition and recall of a brand whereas brand image has to do with associations of customers on a particular brand, their attitudes and benefits of the brand (functional, experimental and symbolic). When it comes to Vazquez et al. (2002), they defined consumer-based brand equity as the entirety of benefits including functional and symbolic ones that could accrue as a result of using a particular brand. For the marketing perspective, functional experimental and symbolic benefits are important for creating the brand equity. Hence, this research focuses on the consumer based brand equity in order to describe the consumer's attitudes towards tracksuit brands.

Literature offers a diversity of studies with regard to brand equity in consumer goods such as studies on detergents by Kamakura and Russel (1993), Leuthesser (1995), studies on toothpaste and mouthwash by Park and Srinavasan (1994), studies on cars and TVs by Pappu, Quester \& Cooksey (2005). One can encounter studies on training shoes in sports products (Buil, de Chernatony \& Martinez, 2008; Koçak, Abimbola \& Özer, 2007; Netemeyer et al., 2004; Tong \& Hawley, 2009a; Vazquez et al., 2002; Yoo \& Donthu, 2001). Studies on sportswear and training shoes (Tong \& Hawley, 2009b) abound, however one cannot come across any studies regarding brand equity in tracksuit brands. Within this framework, the objective of this study was to measure brand equity in tracksuit brands, to contribute to literature by analysing purchasing behaviour of consumers in tracksuit category and to offer suggestions to sports marketers.

\section{METHODS}

Research Model. In this study, quantitative research method was used. Correlational design and prediction design was selected because this is a powerful statistical procedure that can estimate the collective as well as the individual contributions of all predictor variables.

Participants and Instruments. A total of 250 undergraduate students, studying at the Celal Bayar University, Faculty of Sport Sciences, were selected for research using random sampling strategy: $32 \%$ of the study group were engaged in football, 23\% - in basketball, 20\% - in volleyball, $11 \%$ - in handball and $14 \%$ - in swimming, tennis, gymnastics, far-east sports and other branches. "Consumer-Based Brand Equity Scale (CBBE)" was implemented and developed by Vazquez 
et al. (2002). The validity and reliability of the Turkish form were confirmed by Koçak et al. (2007) in order to measure consumer-based brand equity with regards to tracksuit brands through demographic questions. The Turkish form of the CBBE is a 5-point Likert type measurement tool and it consists of 16 items. Data gathering was completed by face to face interviews.

Data Analysis. Data were analysed by utilizing descriptive statistics, student's $t$ test, one-way analysis of variance and logistic regression analysis. In this study, the Cronbach alpha value of the scale was found as .87 as a result of reliability analysis. Nunnally \& Bernstein (1994) suggested that the cutoff value for reliability was accepted as .70 . Fitting the normal distribution was analysed to determine the differentiation test. Skewness values were - .64.15 and Kurtosis values were $.33-.30$. KolmogorovSmirnov test was used to test the normality. According to D'Agostino (1971), data was normally distributed (test statistic $=.02, p=.17$ ).

\section{RESULTS}

In this study, explanatory and confirmatory factor analysis was used in order to test the validity of the scale. As a result of explanatory factor analysis (EFA), factor loadings were checked and found to vary between .56 and .76 and the average variance extracted (AVE) was found to be $67 \%$.
The calculated AVE value should be greater than 0.50 (Fornell \& Larcker, 1981). According to confirmatory factor analysis (CFA) results, the following has been observed: $C F I=.97, G F I=$ $.91, R M S E A=.06$, Chi-Square/df $(193.56 / 97)=$ 1.99. Factor loadings of items were between .50 and .71 and all factor loadings were greater than 0.50 (Hair et al., 1998) with meaningful $t$-values. It can be suggested that the scale meets all criteria depending on these findings (SchermellehEngel \& Moosbrugger, 2003). Consequently, the measurement tool can be said to be valid and reliable.

Among the research participants, $63.6 \%$ of the athletes who participated in the research were men whereas $36.4 \%$ were women, and the average age was 22. Most preferred tracksuit brands in the light of study results were as follows: Adidas (56\%), Nike (25.6\%), Puma (4.4\%), Reebok (4.4\%), Kinetix (2.8\%) and Slazenger (0.8\%). The ranking according to consumer-based brand equity was as follows: Adidas $(M=4.00)$, Reebok $(M=3.91)$, Kinetix $(M=3.90)$, Nike $(M=3.88)$, Slazenger $(M=3.68)$, Puma $(M=3.64)$.

As shown in Table 2, there were no statistically significant differences among consumer-based brand equities of tracksuit brands based on gender, age, purpose of usage and time to purchase a new tracksuit. Nevertheless, significant differences were observed in terms of the money paid for

\begin{tabular}{|c|c|c|c|c|c|}
\hline Variables & Sub-dimensions & Items & Cronbach $\alpha$ & AVE & Factor loadings \\
\hline \multirow{6}{*}{$\begin{array}{l}\text { Product } \\
\text { utility }\end{array}$} & \multirow{2}{*}{ Comfort } & I1 & \multirow{6}{*}{.71} & \multirow{6}{*}{50.18} & .76 \\
\hline & & $\mathrm{I} 2$ & & & .75 \\
\hline & \multirow{4}{*}{ Safety } & $\mathrm{I} 3$ & & & .46 \\
\hline & & I4 & & & .64 \\
\hline & & I5 & & & .68 \\
\hline & & I6 & & & .69 \\
\hline \multirow{10}{*}{$\begin{array}{l}\text { Brand name } \\
\text { utility }\end{array}$} & \multirow{3}{*}{ Guarantee } & I7 & \multirow{10}{*}{.84} & \multirow{10}{*}{17.29} & .56 \\
\hline & & I8 & & & .62 \\
\hline & & I9 & & & .65 \\
\hline & \multirow{3}{*}{$\begin{array}{c}\text { Social } \\
\text { identification }\end{array}$} & I10 & & & .63 \\
\hline & & I11 & & & .87 \\
\hline & & $\mathrm{I} 12$ & & & .80 \\
\hline & \multirow{2}{*}{ Status } & $\mathrm{I} 13$ & & & .70 \\
\hline & & $\mathrm{I} 14$ & & & .63 \\
\hline & \multirow{2}{*}{$\begin{array}{c}\text { Personal } \\
\text { identification }\end{array}$} & $\mathrm{I} 15$ & & & .70 \\
\hline & & $\mathrm{I} 16$ & & & .69 \\
\hline Scale & & & .87 & 67.48 & \\
\hline
\end{tabular}

Table 1. Reliability and validity of the scale (EFA) 
Table 2. Results of the consumer based brand equity by demographic variables

\begin{tabular}{|c|c|c|c|c|c|}
\hline Demographic variables & $n$ & Mean & $s d$ & $t$ & $p$ \\
\hline \multicolumn{6}{|c|}{ Gender } \\
\hline Female & 91 & 3.95 & .55 & \multirow{2}{*}{.85} & \multirow{2}{*}{.39} \\
\hline Male & 159 & 3.89 & .53 & & \\
\hline \multicolumn{6}{|c|}{ Age } \\
\hline Under 20 years & 54 & 3.80 & .52 & \multirow{2}{*}{-1.73} & \multirow{2}{*}{.08} \\
\hline 21 years and more & 196 & 3.94 & .54 & & \\
\hline \multicolumn{6}{|c|}{ Usage purpose } \\
\hline Sport & 91 & 3.96 & .57 & \multirow{2}{*}{1.15} & \multirow{2}{*}{.24} \\
\hline Convenience & 159 & 3.88 & .52 & & \\
\hline \multicolumn{6}{|c|}{ Payment } \\
\hline Under $\$ 45$ & 172 & 3.82 & .58 & \multirow{2}{*}{-4.97} & \multirow{2}{*}{.00} \\
\hline$\$ 46$ and more & 76 & 4.12 & .34 & & \\
\hline \multicolumn{6}{|c|}{ Number of tracksuits } \\
\hline $1-2$ pieces & 42 & 3.75 & .58 & \multirow{2}{*}{-2.19} & \multirow{2}{*}{.02} \\
\hline 3-4 pieces & 128 & 3.95 & .52 & & \\
\hline \multicolumn{6}{|c|}{ Buying frequency } \\
\hline Less than 6 months & 125 & 3.95 & .55 & \multirow{3}{*}{.90} & \multirow{3}{*}{.40} \\
\hline 6-12 months & 97 & 3.90 & .54 & & \\
\hline 1 year or more & 28 & 3.80 & .45 & & \\
\hline
\end{tabular}

each tracksuit brand and the number of tracksuits owned. The perception of consumer-based brand equity of those who paid $\$ 46$ and more and more for tracksuit brands and who owned 3-4 tracksuits was different than that of the others.

Table 3. Results of the logistic regression analysis

\begin{tabular}{|l|c|c|c|c|}
\hline \multicolumn{1}{|c|}{ Variables } & $\boldsymbol{B}$ & $\boldsymbol{S} \boldsymbol{E} \boldsymbol{B}$ & $\boldsymbol{p}$ & $\boldsymbol{\beta} \boldsymbol{p}$ \\
\hline Gender & -.56 & .29 & .058 & .57 \\
\hline Age & .51 & .31 & .10 & 1.67 \\
\hline Purpose of usage & -.22 & .28 & .43 & .80 \\
\hline Number of tracksuit & .47 & .34 & .17 & 1.60 \\
\hline Payment & 1.32 & .36 & .00 & 3.77 \\
\hline Buying frequency $=1$ & -.27 & .44 & .52 & .75 \\
\hline Buying frequency $=2$ & -.12 & .45 & .78 & .88 \\
\hline
\end{tabular}

It was also found that consumer-based brand equity had an impact on the money paid for the tracksuit which was an input as model-dependent variable $(\beta=1.32, p=.00, \operatorname{Exp} . \beta p=3.77)$. According to this finding, all variables being constant, a rise of 1 unit in the perception of brand equity of a tracksuit brand increased the money to be paid for that tracksuit by 3.77 times, which demonstrates the fact that a surge in brand equity enhances the willingness to pay more for a tracksuit brand.

\section{DISCUSSION}

The brand equity of tracksuits did not alter depending on gender, the reason of which could be that the quality and convenience of tracksuits were the same both in men and women. The sportspeople were of similar age, thus there was no difference in brand equity in terms of age variable. Sportspeople were found to wear tracksuits both to work out and to wear comfortably. Even though there were no perceived differences among brand equities for consumers buying tracksuits in terms of time to purchase a tracksuit (every 6 months, every 6-12 months, every 12-18 months), it was observed that brand equity score average diminished as the interval got longer. This finding attests to the fact that customers adhere to their particular brand and tend to be more loyal since they perceive their particular brand to have higher equity. Brand equity differs in conjunction with the number of tracksuits owned by sportspeople. 
Those having three and more tracksuits were observed to consider their brand to have higher brand equity compared to those having 1 or 2 tracksuits, which is a testimony to the fact that consumers who assumed their brand to have higher brand equity were inclined to purchase more from that brand (Ailawadi et al., 2003; Raggio \& Leone, 2007). In parallel to this, customers who paid more for tracksuit brands reckoned that their particular brand had higher brand equity compared to those who paid less. Consumers who deemed their brand to have higher equity were evidently more willing to pay more for that particular brand.

Another finding of the study reveals that the rise in brand equity of tracksuits renders customers more eager to pay more, which runs similar to studies (Homburg, Koschate, \& Hoyer, 2005; Koschate-Fisher, Diamantopoulos, \& Oldenkotte, 2012; Raggio \& Leone, 2007; Y1ld1z, 2012; Zeithaml, Berry, \& Parasuraman, 1996) laying bare the fact that high brand equity and its components (brand satisfaction, trust in brand, brand associations) boost willingness to pay more. One can infer that high brand equity diminishes price sensitivity, therefore encourages one to pay more.

\section{CONCLUSIONS}

There are two limitations of this study. The first is related to the nature of sample. Because our sample involves Turkish youth, research questions should be tested in different countries and cultures in order to generalize and validate the results. Consumer-based brand equity and consumers' behaviours can be checked via international comparative studies. The second is related to the research variables. Measuring consumer-based brand equity concentrates on the attributes of sport shoes, such as comfort, guarantee, and safety. Further research can investigate other outcome variables such as brand trust, brand satisfaction, switching behaviour, by word of mouth recommendation. In this way, consumer responses towards the tangible attributes of sport shoes can be more clearly explained. Consumers who have higher brand equity are willing to pay more to their favourite brand. It was found that social identification was a most important factor for consumers' choice of sport shoe brand. Sports marketers should attractively and strongly use the social marketing and media tools to gain success on social identification building and positioning.

\section{REFERENCES}

Aaker, D. A. (1991). Managing brand equity. New York, NY: The Free Press.

Ailawadi, K. L., Lehmann, D. R., \& Neslin, S. A. (2003). Revenue premium as an outcome measure of brand equity. Journal of Marketing, 67, 1-17. Retrieved form http://www.jstor.org/stable/30040546

Ambler, T., \& Styles, C. (1996). Brand development versus new product development: Toward a process model of extension decisions. Marketing Intelligence \& Planning, 14(7), 10-19.

Aktuğlu, K. I. (2008). Brand management: Basic principles for strong and successful brands, İletişim Publishing ( $2^{\text {nd }}$ ed.): İstanbul.

Buil, I., de Chernatony, L., \& Martinez, E. (2008). A cross-national validation of the consumerbased brand equity scale. Journal of Product \& Brand Management, 17(6), 384-392. http://dx.doi. org/10.1108/10610420810904121

D'Agostino, R. B. (1971). An omnibus test of normality for moderate and larger size samples. Biometrica, 58(2), 341-358.

de Chernatony, L., \& Riley, F. D. (1998). Defining a "Brand": Beyond the literature with experts' interpretations. Journal of Marketing Management, 14, 417-443.
Farquhar, P. H. (1989). Managing brand equity. Marketing Research, 1(3), 24-33.

Hair, J. F., Anderson, R. E., Tatham, R. L., \& Black, W. C. (1998). Multivariate Data Analysis (5th ed.). Englewood Cliffs, NJ: Prentice-Hall: 612.

Homburg, C., Koschate, N., \& Hoyer, W. D. (2005). Do satisfied customers really pay more? A study of the relationship between customer satisfaction and willingness to pay. Journal of Marketing, 69(2), 84-96. doi: $10.1509 / \mathrm{jmkg} .69 .2 .84 .60760$

Kamakura, W., \& Russell, G. (1993). Measuring brand value with scanner data. International Journal of Research in Marketing, 10, 9-22.

Keller, K. L. (1993). Conceptualizing, measuring, and managing customer-based brand equity. Journal of Marketing, 57(1), 1-22.

Koçak, A., Abimbola, T., \& Özer, A. (2007). Consumer brand equity in a cross cultural replication: An evaluation of a scale. Journal of Marketing Management, 23(1-2), 157-173. http://dx.doi.org/10.1362/026725707X178611 Koschate-Fischer, N., Diamantopoulos, A., \& Oldenkotte, K. (2012). Are consumers really willing to pay more for a favorable country image? A study of country-of-origin effects on willingness to pay. Journal 
of International Marketing, 20(1), 19-41. https:// journals.ama.org/doi/abs/10.1509/jim.10.0140

Kotler, P., Wong, V., Saunders, J., \& Armstrong, G. (2005). Principles of Marketing. Pearson Education Limited: Fourth European Edition.

Leuthesser, L. (1988). Defining, measuring and managing brand equity: A conference summary. Cambridge, MA: Marketing Science Institute.

Netemeyer, R. G., Krishnan B., Pullig, C., Wang, G., Yağci M., Dean D., ... Wirth, F. (2004). Developing and validating measures of facets of customer-based brand equity. Journal of Business Research, 57, 209-224. Retrieved from http://econpapers.repec.org/RePEc:eee: jbrese:v:57:y:2004:i:2:p:209-224

Nunnally, J. C., \& Bernstein, I. R. (1994). Psychometric Theory (3rd ed.). New York: McCraw-Hill.

Pappu, R., Quester, P. G., \& Cooksey, R. W. (2005). Consumer-based brand equity: Improving the measurement-empirical evidence. The Journal of Product and Brand Management, 14(2/3), 143-154. http://dx.doi.org/10.1108/10610420510601012

Park, C. S., \& Srinavasan, V. (1994). A survey-based method for measuring and understanding brand equity and its extendibility. Journal of Marketing Research, XXXI, 271-288.

Raggio, R. D., \& Leone, L. P. (2007). The theoretical separation of brand equity and brand value: Managerial implications for strategic planning. Journal of Brand Management, 14, 380-395. Retrieved from https://pdfs. semanticscholar.org/.../7da260c1ac7deb3476405ac03b

Schermelleh-Engel, K., \& Moosbrugger, H. (2003). Evaluating the fit of structural equation models: Tests of significance and descriptive goodness-of-fit measures. Methods of Psychological Research Online, 8(2), 23-74.

Tek, Ö. B., \& Özgül, E. (2005). Modern Marketing Principles. İzmir: Birleşik Publishing.

Tong, X., \& Hawley, J. M. (2009a). Measuring customer-based brand equity: Empirical evidence from the sportswear market in China. Journal of Product \& Brand Management, 18(4), 262-271. doi: 10.1108/10610420910972783

Tong, X., \& Hawley, J. M. (2009b). Creating brand equity in the Chinese clothing market. Journal of Fashion Marketing and Management: An International Journal, 13(4), 566-581. doi: 10.1108/13612020910991411

Vazquez, R., del Rio, A. B., \& Iglesias, V. (2002). Consumer-based brand equity: Development and validation of a measurement instrument. Journal of Marketing Management, 18, 27-48. http://dx.doi. org/10.1362/0267257022775882

Yoo, B., \& Donthu, N. (2001). Developing and validating a multidimensional consumer-based brand equity scale. Journal of Business Research, 52, 1-14. doi: 10.1016/ S0148-2963(99)00098-3 .

Yoo, B., Donthu, N., \& Lee, S. (2000). An examination of selected marketing mix elements and brand equity. Academy of Marketing Science, 28(2), 195-211. doi: 10.1177/0092070300282002

Y1ldiz, Y. (2012). Investigation of the effect of the customer satisfaction on the customer loyalty in fitness centers. Selçuk University Journal of Physical Education and Sport Science, 14(2), 217-222.

Zeithaml, V. A., Berry, L. L. \& Parasuraman, A. (1996). The behavioral consequences of service quality. The Journal of Marketing, 60(2), 31-46
Corresponding author Yavuz Yıldız Faculty of Sport Sciences Celal Bayar University 45040 Manisa Turkey Emailyavyildiz@hotmail.com 